\title{
Endothelin Receptor Is Coupled to Phospholipase C via a Pertussis Toxin-insensitive Guanine Nucleotide-binding Regulatory Protein in Vascular Smooth Muscle Cells
}

\author{
Yoh Takuwa, " Yoshitoshi Kasuya, ${ }^{\ddagger}$ Noriko Takuwa, ${ }^{5}$ Michiyo Kudo, ${ }^{*}$ Masashi Yanagisawa," \\ Katsutoshi Goto, ${ }^{\ddagger}$ Tomoh Masaki, ${ }^{\ddagger}$ and Kamejiro Yamashita* \\ *Department of Internal Medicine, Institute of Clinical Medicine, and ${ }^{\ddagger}$ Department of Pharmacology, \\ Institute of Basic Medical Sciences, University of Tsukuba, Ibaraki 305, Japan; and \\ ${ }^{\S}$ Department of Physiology, Faculty of Medicine, University of Tokyo, Tokyo 113, Japan
}

\begin{abstract}
The mechanisms of endothelin-1 (ET) actions were investigated in cultured rat aortic vascular smooth muscle A-10 cells. The A-10 cells have a single class of high affinity binding sites for $E T$ with an apparent $M_{\mathrm{r}}$ of 65,000-75,000 on SDS-PAGE. Stimulation of cells with ET induces mobilization of $\mathrm{Ca}^{2+}$ from both intra- and extracellular pools to produce a biphasic increase in cytoplasmic free $\mathrm{Ca}^{2+}$ concentration. $\mathrm{ET}$ increases cellular levels of inositol trisphosphate and 1,2-diacylglycerol, indicating activation of phospholipase $C$ by ET. ET stimulates production of inositol phosphates in membranes prepared from A-10 cells in the presence of guanosine 5 - $O$-(thiotriphosphate) $(\mathrm{GTP} \gamma \mathrm{S})$, but not in its absence. Further, specific binding of ${ }^{125}$ I-labeled ET to A-10 cell membranes is shown to be inhibited by GTP $\gamma \mathrm{S}$ in a dose-dependent manner. Treatment of A-10 cells with pertussis toxin induces ADP-ribosylation of a 41,000-D membrane protein but fails to block the ET-induced increases in inositol phosphate production and $\mathrm{Ca}^{2+}$ mobilization. These results indicate that the receptor for ET is coupled to phospholipase $\mathbf{C}$ via a guanine nucleotide-binding regulatory protein which is distinct from the pertussis toxin substrate in A-10 cells. (J. Clin. Invest. 1990. 85:653-658.) phosphoinositide hydrolysis $\bullet$ inositol phosphate $\cdot 1,2$-diacylglycerol $\bullet \mathrm{Ca}^{2+}$ channel • vasoconstriction
\end{abstract}

\section{Introduction}

Endothelin-1 (ET), ${ }^{1}$ a novel peptide produced by vascular endothelial cells, is one of the most potent vasoconstrictors known so far $(1,2)$. Our previous studies demonstrated that activation by $\mathrm{ET}$ of the voltage-dependent $\mathrm{Ca}^{2+}$ channel plays an important role in ET-induced vasoconstriction (1-3). Sub-

Address correspondence to Dr. Yoh Takuwa, Department of Internal Medicine, Institute of Clinical Medicine, University of Tsukuba, Tsukuba, Ibaraki 305, Japan.

Received for publication 19 June 1989 and in revised form 21 September 1989.

1. Abbreviations used in this paper: $\left[\mathrm{Ca}^{2+}\right]_{i}$, intracellular $\mathrm{Ca}^{2+}$ concentration; ET, endothelin-1; GTP $\gamma \mathrm{S}$, guanosine $5^{\prime}-O$-(thiotriphosphate); $\mathrm{IP}_{1}$, inositol monophosphate; $\mathrm{IP}_{2}$, inositol bisphosphate; $\mathrm{IP}_{3}$, inositol trisphosphate; $\left[{ }^{32} \mathrm{P}\right] N A D$, [adenylate- $\left.{ }^{32} \mathrm{P}\right]$ nicotinamide; $\mathrm{PCA}$, perchloric acid.

J. Clin. Invest.

(c) The American Society for Clinical Investigation, Inc.

0021-9738/90/03/0653/06 \$2.00

Volume 85, March 1990, 653-658 sequent studies by us and other investigators have revealed that ET also stimulates phospholipase $\mathrm{C}$ to produce inositol trisphosphate $\left(\mathrm{IP}_{3}\right)$ and to mobilize intracellular $\mathrm{Ca}^{2+}$ in vascular smooth muscle (4-9) and other types of cells $(10,11)$. These results suggest that ET activates the dual transmembrane signaling pathways in the target cells, i.e., inositol phospholipid hydrolysis and $\mathrm{Ca}^{2+}$ channel gating.

Recent studies have established a pivotal role for the hydrolysis products of inositol phospholipids as second messengers in actions of numerous hormones $(12,13)$. In many cases receptor stimulation by these $\mathrm{Ca}^{2+}$-mobilizing hormones is coupled to phospholipase $\mathrm{C}$ activation via guanine nucleotidebinding regulatory proteins ( $G$ proteins) $(14,15)$. In some instances, however, the activation of phospholipase $C$ is a secondary event resulting from either agonist-induced stimulation of $\mathrm{Ca}^{2+}$ influx across the plasma membrane $(16,17)$ or some other mechanisms including phosphorylation by a receptor-tyrosine kinase of phospholipase $C(18)$. At present, the nature of ET receptor(s) and the mechanism by which the receptor activation is coupled to phospholipase $C$ stimulation are not known.

In the present study, to understand in depth ET actions in vascular smooth muscle, we tried to characterize the receptor and the signal transduction mechanisms of ET using cultured rat aortic vascular smooth muscle cells (A-10 cells). We concluded from the results that ET binds to and activates a single class of high affinity receptors which are coupled to phospholipase $C$ via a pertussis toxin-insensitive $G$ protein.

\section{Methods}

Cell culture and materials. A-10 cells were obtained from American Type Culture Collection through Dainippon Seiyaku (Kyoto, Japan). Cells were grown in DME (Nissui Seiyaku, Tokyo, Japan) supplemented with 10\% FCS (M.A. Bioproducts, Walkersville, MD), 100 $\mu \mathrm{g} / \mathrm{ml}$ streptomycin, and $100 \mathrm{U} / \mathrm{ml}$ penicillin $\mathrm{G}$ (Meiji Seika, Tokyo, Japan) at $37^{\circ} \mathrm{C}$ in a fully humidified atmosphere of $5 \% \mathrm{CO}_{2}$ in air. For experimental purposes, confluent cells were serum-deprived by culturing in DME containing 0.3\% BSA for $24 \mathrm{~h}$.

Human ET, obtained from Peptide Institute (Osaka, Japan), was dissolved at $10^{-4} \mathrm{M}$ in Dulbecco's PBS containing $0.5 \%$ BSA and stored in aliquots at $-20^{\circ} \mathrm{C}$. Dilutions were made immediately before use. Fura-2 acetoxymethyl ester was purchased from Wako (Tokyo, Japan). Nicardipine was generously provided by Yamanouchi Pharmaceutical Co. Ltd. (Tokyo, Japan). Myo-[2- $\left.{ }^{3} \mathrm{H}\right] \mathrm{Inositol}(14.3 \mathrm{Ci} /$ $\mathrm{mmol})$, adenosine $5^{\prime}-\left[\gamma{ }^{32} \mathrm{P}\right]$ triphosphate $(3,000 \mathrm{Ci} / \mathrm{mmol})$, and [adenylate- $\left.{ }^{32} \mathrm{P}\right]$ nicotinamide adenine dinucleotide ([ $\left.\left.{ }^{32} \mathrm{P}\right] \mathrm{NAD}\right)$ were purchased from Dupont/New England Nuclear Research Products (Boston, MA). ${ }^{125} \mathrm{I}-\mathrm{ET}(\sim 2,000 \mathrm{Ci} / \mathrm{mmol})$ was kindly provided by $\mathrm{Dr}$. S. Kimura. Pertussis toxin was purchased from Kaken Seiyaku (Kyoto, 
Japan). Silica gel 60 TLC plate was purchased from E. Merck (Darmstadt, FRG).

${ }^{125}$ I-ET binding experiments. A-10 cells in a 24-well plate were washed with medium A ( $140 \mathrm{mM} \mathrm{NaCl}, 4 \mathrm{mM} \mathrm{KCl}, 1 \mathrm{mM} \mathrm{Na}_{2} \mathrm{HPO}_{4}$, $1 \mathrm{mM} \mathrm{MgCl} 2,1.25 \mathrm{mM} \mathrm{CaCl}_{2} 11 \mathrm{mM}$ glucose, $5 \mathrm{mM}$ Hepes [pH 7.4], and $0.2 \% \mathrm{BSA}$ ) and incubated in medium A containing various concentrations of ${ }^{125} \mathrm{I}$-labeled ET for $30 \mathrm{~min}$ at $25^{\circ} \mathrm{C}$. After washing cells three times with ice-cold medium $\mathrm{A}$, the cell-bound radioactivity was counted. Specific binding was determined as total binding minus nonspecific binding in the presence of $10^{-7} \mathrm{M}$ unlabeled ET.

For experiments to examine the effect of a guanine nucleotide on ${ }^{125}$ I-ET binding to A-10 cell membranes, cells in a $100-\mathrm{mm}$ dish were washed twice with PBS, scraped into a solution containing $250 \mathrm{mM}$ sucrose, $1 \mathrm{mM} \mathrm{MgCl}$, and $10 \mathrm{mM}$ Tris/ $\mathrm{HCl}$ (pH 7.4), and homogenized with a glass-glass homogenizer at $4^{\circ} \mathrm{C}$. After centrifugation at $200 \mathrm{~g}$ for $10 \mathrm{~min}$ at $4^{\circ} \mathrm{C}$ the supernatant was centrifuged at $10,000 \mathrm{~g}$ for $5 \mathrm{~min}$ at $4^{\circ} \mathrm{C}$ and the resulting pellet was resuspended in a $10-\mathrm{mM}$ Tris/ $\mathrm{HCl}$ buffer (pH 7.4) containing $120 \mathrm{mM} \mathrm{NaCl}$ and $3 \mathrm{mM} \mathrm{MgCl}$. ${ }^{125} \mathrm{I}$-ET was incubated with $25 \mu \mathrm{g}$ membrane protein in the presence of various concentrations of guanosine $5^{\prime}-O$-(thiotriphosphate) (GTP $\gamma$ S) for $24 \mathrm{~h}$ at $4^{\circ} \mathrm{C}$. The incubation mixtures were filtered through $\mathrm{GF} / \mathrm{F}$ filters (Whatman Laboratory Products Inc., Clifton, $\mathrm{NJ}$ ) and the radioactivity associated with the filters was measured with a gamma counter. Nonspecific binding was determined in the presence of $10^{-6}$ M unlabeled ET.

Affinity cross-linking of ${ }^{I 25} I-E T$. A-10 cells in a $35-\mathrm{mm}$ plastic dish were incubated at $25^{\circ} \mathrm{C}$ in medium A containing $3 \times 10^{-10} \mathrm{M}^{125} \mathrm{I}$-ET in the presence or absence of $10^{-7} \mathrm{M}$ unlabeled ET for $30 \mathrm{~min}$. The cells were washed two times with PBS and incubated with $1 \mathrm{mM}$ ethylene glycolbis (succinimidyl succinate) in BSA-free medium A at $22^{\circ} \mathrm{C}$ for $50 \mathrm{~min}$. The cells were rapidly washed twice with PBS and solubilized in $0.5 \mathrm{ml}$ of the sample buffer $(62.5 \mathrm{mM}$ Tris- $\mathrm{HCl}$ [pH 6.8], $10 \%$ glycerol, $2.3 \%$ SDS, and $5 \% \beta$-mercaptoethanol). After boiling at $100^{\circ} \mathrm{C}$ for $3 \mathrm{~min}$ the samples were analyzed by $10 \%$ SDS-PAGE followed by autoradiography.

Determination of intracellular $\mathrm{Ca}^{2+}$ concentration $\left(\left[\mathrm{Ca}^{2+}\right]_{i}\right)$. A-10 cells were dispersed by $0.025 \%$ trypsin treatment and loaded with fura- 2 by incubating cells in medium A containing $4 \mu \mathrm{M}$ fura- 2 acetoxymethyl ester for $45 \mathrm{~min}$ at $20^{\circ} \mathrm{C}$. The fluorescence of fura-2-loaded cells was measured with a CAF-100 spectrofluorimeter (Japan Spectroscopy, Inc., Tokyo, Japan) with excitation at 340 and $380 \mathrm{~nm}$ and emission at $500 \mathrm{~nm}$ as previously described (11). The free $\mathrm{Ca}^{2+}$ concentration was calculated from the measurements of the ratio of fluorescence intensities as described by Grynkiewicz et al. (19).

Measurements of inositol phosphate production and cellular 1,2diacylglycerol content. For measurement of inositol phosphate production, cells were prelabeled with $m y o-\left[2-{ }^{3} \mathrm{H}\right]$ inositol $(4 \mu \mathrm{Ci} / \mathrm{ml})$ in DME containing $0.3 \%$ BSA for $24 \mathrm{~h}$ and stimulated by various concentrations of ET for indicated time periods at $37^{\circ} \mathrm{C}$. The reaction was stopped by replacing media with ice-cold $10 \%$ perchloric acid (PCA) solution. The neutralized PCA extract was analyzed for inositol phosphates using Dowex columns as described (20). The cellular content of 1,2-diacylglycerol was measured by an enzymatic method using an Escherichia coli diacylglycerol kinase according to the method described by Preiss et al. (21).

Measurement of inositol phosphate production in the plasma membranes. A-10 cell membranes were obtained as described above, except that the homogenization buffer contained $250 \mathrm{mM}$ sucrose, $1 \mathrm{mM}$ EGTA, $1 \mathrm{mM}$ ATP, $0.1 \mathrm{mM} \mathrm{MgCl}_{2}$, and $10 \mathrm{mM}$ Tris/ $\mathrm{HCl}$ (pH 7.4), and membranes were resuspended in a buffer containing $5 \mathrm{mM}$ $\mathrm{MgCl}_{2}, 1 \mathrm{mM}$ EGTA, $10 \mathrm{mM} \mathrm{LiCl}$, and $50 \mathrm{mM}$ Hepes/ $\mathrm{NaOH}(\mathrm{pH}$ 7.4). The membranes were incubated with $10^{-7} \mathrm{M} \mathrm{ET}$ and/or various concentrations of GTP $\gamma \mathrm{S}$ in the presence of $10^{-7} \mathrm{M}$ free $\mathrm{Ca}^{2+}$ concentration determined by a Ca ${ }^{2+}$-EGTA buffer (22) at $37^{\circ} \mathrm{C}$ for $1 \mathrm{~min}$. The reaction was terminated by addition of PCA (a final concentration of $10 \%$ ) and analyzed for inositol phosphates as described above.

In vitro ADP-ribosylation of A-10 cell membranes. A-10 cells, either untreated or treated with $10 \mathrm{ng} / \mathrm{ml}$ pertussis toxin for $24 \mathrm{~h}$, were

washed twice with PBS, scraped, and homogenized in a homogenization buffer containing $5 \mathrm{mM}$ EDTA, $1 \mathrm{mM}$ dithiothreitol, and $10 \mathrm{mM}$ Tris/ $\mathrm{HCl}(\mathrm{pH}$ 7.4). The homogenates were briefly sonicated and centrifuged at $10,000 \mathrm{~g}$ for $5 \mathrm{~min}$ at $4^{\circ} \mathrm{C}$. The resulting pellet was resuspended in a homogenization buffer. The membranes $(30 \mu \mathrm{g})$ were incubated with $25 \mu \mathrm{g} / \mathrm{ml}$ pertussis toxin for $75 \mathrm{~min}$ at $25^{\circ} \mathrm{C}$ in $20 \mathrm{mM}$ Tris/ $\mathrm{HCl}$ buffer $(\mathrm{pH} 7.5)$ containing $10 \mathrm{mM}$ thymidine, $40 \mu \mathrm{M}\left[{ }^{32} \mathrm{P}\right]-$ NAD, $1 \mathrm{mM}$ ATP, $0.5 \mathrm{mM}$ EDTA, $20 \mathrm{mM}$ dithiothreitol, and $1 \mathrm{mM}$ $\mathrm{MgCl}_{2}$. The reaction was terminated with TCA (a final concentration of $10 \%$ ) and the pellet was solubilized in the SDS-sample buffer and analyzed by $8 \%$ SDS-PAGE followed by autoradiography.

\section{Results}

Specific binding and affinity cross-linking of ${ }^{125}$ I-ET to A-10 cells. To characterize the specific binding site for ET in A-10 cells, a radioligand binding assay was performed using $\left[{ }^{125} \mathrm{I}\right] \mathrm{ET}$ (Fig. 1). Specific binding was $>76 \%$ of total binding at any concentration of $\left[{ }^{125} \mathrm{I}\right] \mathrm{ET}$ tested and was a saturable process (Fig. $1 \mathrm{~A}$ ). Scatchard analysis of the data revealed a single class of high affinity binding sites with a $K_{\mathrm{d}}$ of $3 \times 10^{-10} \mathrm{M}$ and a $B_{\max }$ of 67,000 binding sites per cell (Fig. $1 B$ ). Affinity crosslinking of $\left[{ }^{125} \mathrm{I}\right] \mathrm{ET}$ to receptors with a cross-linking reagent, ethylene glycolbis (succinimidyl succinate), revealed the presence of a single major band with an $M_{\mathrm{r}}$ of 65,000-75,000 on the SDS-PAGE (Fig. $1 C$ ). In the presence of 300 -fold excess unlabeled ET this band was completely abolished.

Effect of ET on $\left[\mathrm{Ca}^{2+}\right]_{i}$ in $\mathrm{A}-10$ cells. The ET-induced $\mathrm{Ca}^{2+}$ mobilization was studied by measurement of changes in $\left[\mathrm{Ca}^{2+}\right]_{i}$, using fura-2 as a $\mathrm{Ca}^{2+}$ indicator (Fig. 2). The baseline

A

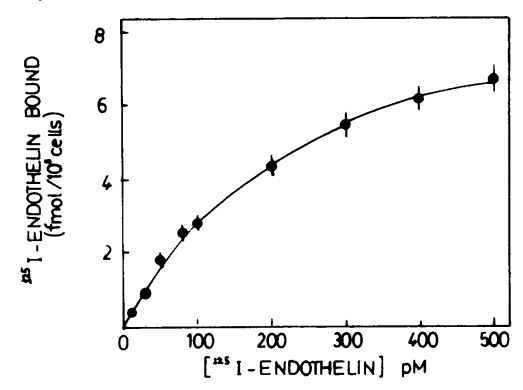

B

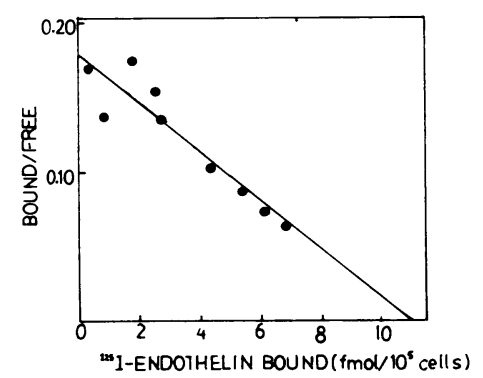

Figure 1. Binding of ${ }^{125}$ I-ET to intact A-10 cells. $A$, Specific binding of ${ }^{125}$ I-ET. The data represent the means \pm SD of three determinations. $B$, Scatchard plot for specific binding of ${ }^{125}$ I-ET. $C$, Affinity cross-linking of ${ }^{125} \mathrm{I}-\mathrm{ET}$ in the absence (left) or presence (right) of an excess amount of nonlabeled ET. Molecular weight standards $\left(\times 10^{-3}\right)$ are shown on the left. The gel was exposed to a film for $12 \mathrm{~d}$ at $-80^{\circ} \mathrm{C}$. 


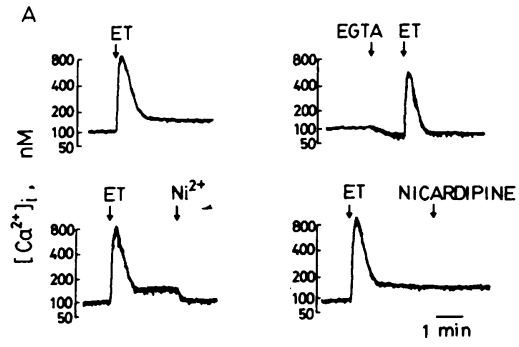

B

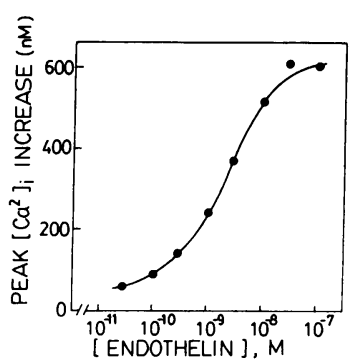

Figure 2. Effect of ET on $\left[\mathrm{Ca}^{2+}\right]_{\mathrm{i}} \cdot A$, Effects of EGTA $\left(2 \times 10^{-3} \mathrm{M}\right)$, $\mathrm{Ni}^{2+}\left(1 \times 10^{-3} \mathrm{M}\right)$, and nicardipine $\left(1 \times 10^{-6}\right.$ M) on $10^{-7}$ M ET-induced increase in $\left[\mathrm{Ca}^{2+}\right]_{\mathrm{i}}$. Test substances were applied at arrows and were present throughout each recording. Tracings are representative of at least four experiments. $B$, Doseresponse curve of ETinduced increases in $\left[\mathrm{Ca}^{2+}\right]_{i}$. Each value expresses the mean of four to six determinations.

$\left[\mathrm{Ca}^{2+}\right]_{\mathrm{i}}$ was $92 \pm 11 \mathrm{nM}($ mean $\pm \mathrm{SD}, n=34)$. Addition of $10^{-7}$ $M$ ET induced a prompt rise in $\left[\mathrm{Ca}^{2+}\right]_{i}$, which peaked within $15 \mathrm{~s}$ of ET addition with a peak value of $686 \pm 24 \mathrm{nM}(n=4)$ (Fig. $2 \mathrm{~A})$. The $\left[\mathrm{Ca}^{2+}\right]_{\mathrm{i}}$ then fell to a lower plateau level $(160 \pm 4$ $\mathrm{nM}$ at $3 \mathrm{~min}, n=4)$, which was significantly higher than the baseline value. The peak $\left[\mathrm{Ca}^{2+}\right]_{\mathrm{i}}$ increase was dose dependent and became greater with increasing doses of ET (Fig. $2 \mathrm{~B}$ ). The response was saturated with $3 \times 10^{-8} \mathrm{M} E T$. The $\mathrm{ED}_{50}$ for ET-induced increases in $\left[\mathrm{Ca}^{2+}\right]_{\mathrm{i}}$ was estimated to be $\sim 3$ $\times 10^{-9} \mathrm{M}$. When extracellular $\mathrm{Ca}^{2+}$ was lowered by adding 2 mM EGTA (free $\mathrm{Ca}^{2+}, 200 \mathrm{nM}$ ), the basal $\left[\mathrm{Ca}^{2+}\right]_{\mathrm{i}}$ declined to a new steady-state level (Fig. $2 A$ ). Under such a condition, ET $\left(10^{-7} \mathrm{M}\right)$ still induces the initial $\mathrm{Ca}^{2+}$ transient, but not the second plateau of the $\left[\mathrm{Ca}^{2+}\right]_{i}$ response. In the presence of 1.25
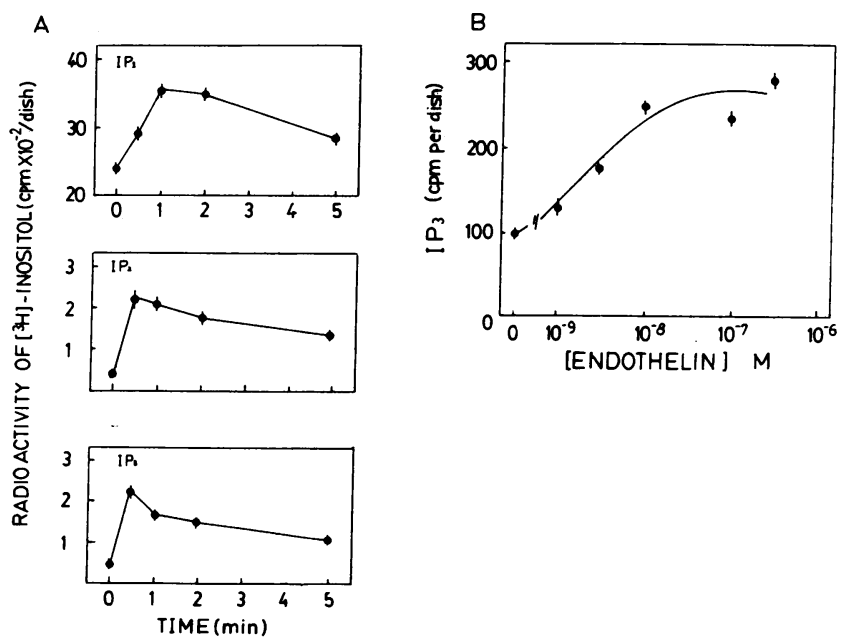

Figure 3. Effect of ET on inositol phosphate generation. $A$, Time course of changes in inositol phosphates when $\left[{ }^{3} \mathrm{H}\right]$ inositol-labeled A-10 cells were stimulated with $10^{-7}$ M ET. $B$, Dose-response curve of ET-induced increases in $\mathrm{IP}_{3}$. The data represent the mean $\pm \mathrm{SD}$ of three determinations.

Table I. Effect of ET on Cellular 1,2-Diacylglycerol Content in A-10 Cells

\begin{tabular}{cc}
\hline Time & 1,2-Diacylglycerol \\
\hline & nmol/dish \\
0 & $0.193 \pm 0.007$ \\
$20 \mathrm{~s}$ & $0.265 \pm 0.006$ \\
$1 \mathrm{~min}$ & $0.313 \pm 0.016$ \\
$2 \mathrm{~min}$ & $0.367 \pm 0.013$ \\
$5 \mathrm{~min}$ & $0.437 \pm 0.018$
\end{tabular}

Confluent monolayer cells were incubated with $10^{-7} \mathrm{M}$ ET for indicated time periods and 1,2-diacylglycerol content was measured.

Data are the mean \pm SD of three determinations.

$\mathrm{mM} \mathrm{CaCl}$, addition of $1 \mathrm{mM} \mathrm{Ni}^{2+}$, an inorganic $\mathrm{Ca}^{2+}$ channel blocker, promptly abolished the second plateau phase of the $\left[\mathrm{Ca}^{2+}\right]_{\mathrm{i}}$ response to ET (Fig. $2 \mathrm{~A}$ ). These findings suggest that ET induces $\mathrm{Ca}^{2+}$ mobilization from both intra- and extracellular pools. Previous studies suggested that ET acts on porcine coronary artery smooth muscle cells to activate a dihydropyridine-sensitive $\mathrm{Ca}^{2+}$ channel. However, in the present study a dihydropyridine $\mathrm{Ca}^{2+}$ channel antagonist, nicardipine, did not inhibit the plateau phase of the $\left[\mathrm{Ca}^{2+}\right]_{\mathrm{i}}$ response to ET at concentrations up to $1 \times 10^{-6} \mathrm{M}$ in A-10 cells (Fig. $2 \mathrm{~A}$ ).

Effects of ET on inositol phosphate and 1,2-diacylglycerol production in A-10 cells. As shown in Fig. $3 \mathrm{~A}$, addition of $10^{-7}$ $M$ ET induced rapid rises in inositol bisphosphate $\left(\mathrm{IP}_{2}\right)$ and $\mathrm{IP}_{3}$. The levels of $\mathrm{IP}_{2}$ and $\mathrm{IP}_{3}$ peaked at $30 \mathrm{~s}$ and then gradually declined for the next $4 \mathrm{~min}$. Inositol monophosphate $\left(\mathrm{IP}_{1}\right)$ rose less rapidly than $\mathrm{IP}_{2}$ and $\mathrm{IP}_{3}$, reached a peak at $1 \mathrm{~min}$, and then declined. As shown in Fig. $3 \mathrm{~B}$, ET-induced production of $\mathrm{IP}_{3}$ increased dose dependently. The response was saturated at $10^{-7} \mathrm{M}$ ET. The $\mathrm{ED}_{50}$ value for the response was estimated to be $\sim 3 \times 10^{-9} \mathrm{M}$. The ET-evoked inositol phosphate productions were not significantly affected by extracellular $\mathrm{Ca}^{2+}$ removal, suggesting that ET-induced stimulation of inositol phosphate production is not a result of stimulation of $\mathrm{Ca}^{2+}$ influx across the plasma membrane (data not shown).

Table I shows the time course of ET-induced changes in cellular 1,2-diacylglycerol content. Within $20 \mathrm{~s}$ of ET $\left(10^{-7} \mathrm{M}\right)$ addition, cellular 1,2-diacylglycerol content increased signifcantly and continued to rise for $5 \mathrm{~min}$, when the maximal value of 2.3-fold over the basal level was observed. These results indicate that ET activates phospholipase $C$, which catalyzes the breakdown of polyphosphoinositides in A-10 cells.

Effects of GTPYS on ET binding and ET-induced inositol phosphate production in A-10 cell membranes. To examine whether the receptor for ET was coupled to a $G$ protein, the effect of a nonhydrolyzable GTP analogue, GTP $\gamma$, on the

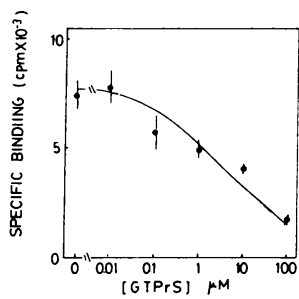

Figure 4. Effect of GTP $\gamma \mathrm{S}$ on the specific binding of ${ }^{125}$ I-ET to A-10 membranes. A-10 membranes were incubated with ${ }^{125}$ I-ET in the presence of various concentrations of GTP $\gamma \mathrm{S}$ for $24 \mathrm{~h}$ at $4^{\circ} \mathrm{C}$ and specific binding of ${ }^{125}$ I-ET to membranes was determined. Values are the mean $\pm S D$ of three determinations. 
Table II. Dependence of ET-stimulated Inositol Phosphate Productions on GTP $\mathrm{S}$

\begin{tabular}{llcr}
\hline \multicolumn{1}{c}{ Additions } & \multicolumn{1}{c}{$\mathbf{I P}_{\mathbf{1}}$} & \multicolumn{1}{c}{$\mathbf{I P}_{\mathbf{2}}$} & $\mathbf{I P}_{\mathbf{3}}$ \\
\hline & & $c p m$ & \\
None & $1,124 \pm 100$ & $52 \pm 10$ & $12 \pm 2$ \\
ET & $1,228 \pm 71$ & $72 \pm 8$ & $15 \pm 5$ \\
GTP $\gamma$ S & $1,166 \pm 90$ & $93 \pm 11$ & $16 \pm 7$ \\
GTP $\gamma$ S + ET & $1,921 \pm 172$ & $319 \pm 30$ & $34 \pm 2$
\end{tabular}

$\left[{ }^{3} \mathrm{H}\right]$ Inositol-prelabeled plasma membranes were incubated with $10^{-7}$ $M$ ET in the presence or absence of $10^{-6} \mathrm{M} \mathrm{GTP \gamma S}$ for $1 \mathrm{~min}$ at $37^{\circ} \mathrm{C}$. Free $\mathrm{Ca}^{2+}$ concentration in the assay buffer was $10^{-7} \mathrm{M}$. Results are mean $\pm \mathrm{SD}$ of three determinations.

specific binding of ET to membranes prepared from A-10 cells was studied. As shown in Fig. 4, GTP $\gamma \mathrm{S}$ inhibited the specific binding of ${ }^{125}$ I-ET to A-10 membranes in a dose-dependent manner. At $100 \mu \mathrm{M}, \mathrm{GTP} \gamma \mathrm{S}$ inhibited the ${ }^{125} \mathrm{I}$-ET binding by $70 \%$.

We next examined the effect of GTP $\gamma \mathrm{S}$ on ET-induced inositol phosphate production in A-10 cell membranes. In the absence of GTP $\gamma \mathrm{S}, 10^{-7} \mathrm{M}$ of ET: alone did not significantly stimulate inositol phosphate prodû́ction (Table II). GTP $\gamma$ S $\left(10^{-6} \mathrm{M}\right)$ by itself had a small stimulating effect on inositol phosphate production (80\%.increase in $\mathrm{IP}_{2}$ and no increase in $\mathrm{IP}_{1}$ and $\left.\mathrm{IP}_{3}\right)$. However, if ET was applied together with GTP $\gamma \mathrm{S}$, a marked increase $(510 \%)$ in $\mathrm{IP}_{2}$ production and significant increases in $\mathrm{IP}_{1}$ and $\mathrm{IP}_{3}\left(70 \%\right.$ in $\mathrm{IP}_{1}$ and $180 \%$ in $\left.\mathrm{IP}_{3}\right)$ were induced. Fig. 5 shows the dose-dependent effects of GTP $\gamma \mathrm{S}$ on ET-induced inositol phosphate $\left(\mathrm{IP}_{2}\right.$ plus $\left.\mathrm{IP}_{3}\right)$ production in A-10 membranes. As little as $10^{-7} \mathrm{M}$ GTP $\gamma \mathrm{S}$ significantly enhanced ET-induced inositol phosphate production.

The effect of pertussis toxin pretreatment on ET-induced inositol phosphate production and $\mathrm{Ca}^{2+}$ mobilization in $\mathrm{A}-10$ cells. As shown in Table III, exposure of intact A-10 cells to 10 $\mathrm{ng} / \mathrm{ml}$ of pertussis toxin for $24 \mathrm{~h}$ did not significantly affect the following ET-induced inositol phosphate production. The extent of labeling of cellular inositol phospholipids with $\left[{ }^{3} \mathrm{H}\right]-$ myoinositol did not significantly differ between pertussis toxin-treated and nontreated cells $(34,100 \pm 10,900$ vs. $36,600 \pm 3,300 \mathrm{cpm}$, mean $\pm \mathrm{SD}[n=6])$. In cells pretreated with pertussis toxin the peak $\left[\mathrm{Ca}^{2+}\right]_{\mathrm{i}}$ increment induced by $10^{-7} \mathrm{M}$ ET was smaller by only $20 \%$ than in nontreated cells $(486 \pm 54$ vs. $600 \pm 95 \mathrm{nM}$; mean $\pm \mathrm{SD}[n=4])$, and the second plateau of the $\left[\mathrm{Ca}^{2+}\right]_{\mathrm{i}}$ response was comparable between pertussis toxin-treated and nontreated cells $(63 \pm 4$ vs. $62 \pm 14$
Table III. Effect of Pertussis Toxin Pretreatment on ET-induced Inositol Phosphate Productions in A-10 Cells

\begin{tabular}{lccccc}
\hline & \multicolumn{2}{c}{ Control } & & \multicolumn{2}{c}{ PT-pretreated } \\
\cline { 5 - 6 } & None & Endothelin & & None & Endothelin \\
\hline & \multicolumn{3}{c}{$c p m$} \\
$\mathrm{IP}_{1}$ & $5,467 \pm 617$ & $7,085 \pm 766$ & $5,025 \pm 551$ & $6,668 \pm 498$ \\
& $(100 \%)$ & $(130 \%)$ & & $(100 \%)$ & $(133 \%)$ \\
$\mathrm{IP}_{2}$ & $78 \pm 12$ & $178 \pm 23$ & $64 \pm 8$ & $177 \pm 20$ \\
& $(100 \%)$ & $(228 \%)$ & $(100 \%)$ & $(277 \%)$ \\
$\mathrm{IP}_{3}$ & $68 \pm 7$ & $171 \pm 7$ & $51 \pm 5$ & $138 \pm 10$ \\
& $(100 \%)$ & $(251 \%)$ & $(100 \%)$ & $(271 \%)$ \\
& & & &
\end{tabular}

Confluent A-10 cells were incubated with $10 \mathrm{ng} / \mathrm{ml}$ pertussis toxin $(P T)$ or vehicle for $24 \mathrm{~h}$ and stimulated with $10^{-7} \mathrm{M}$ ET for $1 \mathrm{~min}$. Results are mean \pm SD of three determinations.

$\mathrm{nM})$. The effectiveness of pertussis toxin pretreatment in intact A-10 cells was proven by the fact shown in Fig. 6 that a $41,000-D$ protein of the plasma membranes prepared from A-10 cells pretreated with pertussis toxin for $24 \mathrm{~h}$ was not significantly ADP-ribosylated in vitro by pertussis toxin in contrast to the membranes prepared from nontreated A-10 cells. These results suggest that a $\mathrm{G}$ protein, distinct from the pertussis toxin substrates, coupled the ET receptor to phospholipase $\mathrm{C}$ in $\mathrm{A}-10$ cells.

\section{Discussion}

Previous studies by us and other investigators demonstrated that ET activates phospholipase $\mathrm{C}$ to produce $\mathrm{IP}_{3}$ and 1,2-diacylglycerol in vascular smooth muscle and other cell types $(5-11)$. The results in the present study confirm these observations and further demonstrate that ET stimulates phospholipase $\mathrm{C}$ by a guanine nucleotide-dependent mechanism in cultured vascular smooth muscle A-10 cells. A-10 cells possess a single class of high affinity receptors for ET (Fig. 1). The binding of ET to the receptors on A-10 cell membranes is inhibited by a nonhydrolyzable GTP analogue, GTP $\gamma \mathrm{S}$, in a dose-dependent manner (Fig. 4). The inhibitory modulation by guanine nucleotides of the binding of various agonists to their respective receptors is a well-known characteristic found in the receptors that interact with $G$ proteins $(23,24)$. Moreover, ET

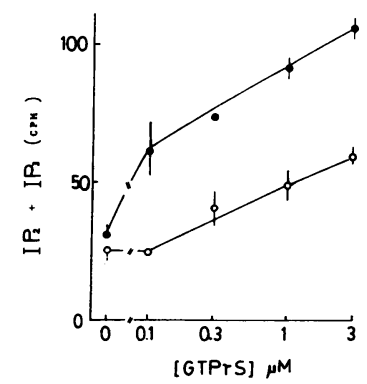

Figure 5. Effect of various concentrations of GTP $\gamma$ S on ET-induced production of inositol phosphate in A-10 membranes. A-10 membranes were incubated with $(\bullet)$ or without $(0) 10^{-7}$ $M E T$ in the presence of various concentrations of GTP $\gamma$ S. The IP 2 and $\mathrm{IP}_{3}$ produced were measured. Values are the mean $\pm \mathrm{SD}$ of three determinations.
Figure 6. In vitro ADP-ribosylation of a $41-\mathrm{kD}$ protein in plasma membranes prepared from A-10 cells nonpretreated or pretreated with pertussis toxin. A-10 cells were incubated with or without $10 \mathrm{ng} / \mathrm{ml}$ of pertussis toxin $(P T)$ for $24 \mathrm{~h}$ and crude membrane fractions were prepared. The membranes were then incubated with $\left[{ }^{32} \mathrm{P}\right] \mathrm{NAD}$ and $25 \mu \mathrm{g} / \mathrm{ml}$ pertussis toxin. Proteins were resolved by SDS-PAGE followed by autoradiography. Arrow indicates the $41-\mathrm{kD}$ protein. Molecular weight standards $\left(\times 10^{-3}\right)$ are shown on the left. 
stimulates polyphosphoinositide hydrolysis in A-10 cell membranes in a manner strictly dependent on GTP $\gamma \mathrm{S}$ (Table II and Fig. 5). These results strongly suggest that the ET receptor is coupled to phospholipase $\mathrm{C}$ by a guanine nucleotide-binding regulatory protein (G protein) in A-10 cells. Pretreatment of A-10 cells with pertussis toxin does not affect ET-induced inositol phosphate production (Table III), even though pertussis toxin fully ADP-ribosylates a 41-kD membrane substrate protein under the identical condition (Fig. 6). These findings suggest that a $G$ protein distinct from pertussis toxin-sensitive $G$ proteins, $\mathrm{Gi}$ or Go (25), couples the ET receptor to phospholipase $\mathrm{C}$ in A-10 cells.

Recent studies on the structure of the $G$ protein-linked receptors, including rhodopsin, adrenergic, muscarinic, and serotoninergic receptors, have revealed that these receptors have considerable similarities in amino acid sequences and share a characteristic membrane-spanning structure (26-28). The molecular weights of these receptors were reported to be in the range of 55,000-80,000 (26-28). In the present study, the affinity cross-linking experiment identified the ET receptor as a single band with an apparent molecular weight of 65,000 75,000 on SDS-PAGE (Fig. 1). These data further support the notion that the ET receptor belongs to the $G$ protein-linked rhodopsin type of receptor superfamily.

The measurements of $\left[\mathrm{Ca}^{2+}\right]_{\mathrm{i}}$ with fura- 2 demonstrate a biphasic pattern of ET-induced $\mathrm{Ca}^{2+}$ mobilization: an initial transient increase in $\left[\mathrm{Ca}^{2+}\right]_{i}$ due to intracellular mobilization, most likely mediated by inositol 1,4,5-trisphosphate (13), and a second sustained plateau phase (Fig. 2). The second plateau phase of the $\left[\mathrm{Ca}^{2+}\right]_{i}$ response to ET is dependent on the presence of extracellular $\mathrm{Ca}^{2+}$, and is blocked by an inorganic $\mathrm{Ca}^{2+}$ channel blocker, $\mathrm{Ni}^{2+}$, suggesting that the second plateau phase is mainly due to $\mathrm{Ca}^{2+}$ influx across the plasma membrane. Our previous study (3) using a patch clamp technique demonstrated that ET acts on porcine coronary artery smooth muscle to activate the dihydropyridine-sensitive (L-type), voltage-dependent $\mathrm{Ca}^{2+}$ channel. However, in A-10 cells a dihydropyridine $\mathrm{Ca}^{2+}$ channel antagonist nicardipine does not inhibit the second plateau of the $\left[\mathrm{Ca}^{2+}\right]_{\mathrm{i}}$ response to ET (Fig. 2). Similar results on cultured vascular smooth muscle cells were recently reported by Mitsuhashi et al. (29). We have found that this is also the case with nonsmooth muscle cells, Swiss 3T3 fibroblasts (11), and MC3T3-El osteoblastic cells (30), which also show a biphasic increase in $\left[\mathrm{Ca}^{2+}\right]_{i}$ in response to ET. It is possible that the apparent discrepancy in the nicardipine effects observed with two different methodologies, measurements of $\left[\mathrm{Ca}^{2+}\right]_{i}$ with fura- 2 and a patch clamp technique, is due to the actual difference in the properties of the $\mathrm{Ca}^{2+}$ channel through which $\mathrm{Ca}^{2+}$ enters into cells in response to ET stimulation in porcine coronary artery smooth muscle and cultured vascular smooth muscle cells. Comparable studies using both methodologies in each cell type may elucidate this point. Although the mechanism of the $\mathrm{Ca}^{2+}$ channel activation by ET in A-10 cells is unknown at present, stimulation of $\mathrm{Ca}^{2+}$ influx which is insensitive to dihydropyridine $\mathrm{Ca}^{2+}$ channel antagonists is commonly observed with numerous $\mathrm{Ca}^{2+}$-mobilizing hormones in various types of cells (31). The failure of pertussis toxin pretreatment to inhibit the second plateau of the $\left[\mathrm{Ca}^{2+}\right]_{\mathrm{i}}$ response to $\mathrm{ET}$ in $\mathrm{A}-10$ cells suggests that activation of the $\mathrm{Ca}^{2+}$ channel by ET is not mediated by the pertussis toxin-sensitive $G$ proteins in these cells as suggested in other types of cells (32). Recent cell-attached patch clamp studies on freshly dispersed porcine coronary artery smooth muscle cells suggested that the activation by ET of the dihydropyridinesensitive, voltage-dependent $\mathrm{Ca}^{2+}$ channel is mediated by a readily diffusible second messenger molecule (33). Thus, the $\mathrm{Ca}^{2+}$ channel activation might be secondary to the proximal membrane signal transduction events, including the activation of phospholipase $\mathrm{C}$ in coronary artery smooth muscle. It would be very interesting to know the precise mechanisms by which ET induces activation of $\mathrm{Ca}^{2+}$ channels in coronary artery smooth muscle and other types of cells.

In conclusion, the present results indicate that the receptor activation by ET is coupled to phosphoinositide hydrolysis through a pertussis toxin-insensitive $G$ protein and gating of dihydropyridine-insensitive $\mathrm{Ca}^{2+}$ channels, leading to $\mathrm{Ca}^{2+}$ mobilization from both intra- and extracellular pools and activation of protein kinase $C$ in cultured aortic vascular smooth muscle. It is suggested that these transmembrane signaling pathways play an important role in mechanisms for ET-induced vasoconstriction (34-36).

\section{Acknowledgments}

We are grateful to Ms. Mana Sakagami for her technical assistance.

This work was supported by grants from the Ministry of Science and Education in Japan, the University of Tsukuba Project Research, and the Tokyo Biochemical Research Foundation.

\section{References}

1. Yanagisawa, M., H. Kurihara, S. Kimura, Y. Tomobe, M. Kobayashi, Y. Yazaki, K. Goto, and T. Masaki. 1988. A novel potent vasoconstrictor peptide produced by vascular endothelial cells. Nature (Lond.). 332:411-415.

2. Kasuya, Y., T. Ishikawa, M. Yanagisawa, S. Kimura, K. Goto, and T. Masaki. 1989. Mechanism of contraction to endothelin in the isolated porcine coronary artery. Am. J. Physiol. In press.

3. Goto, K., Y. Kasuya, N. Matsuki, Y. Takuwa, H. Kurihara, T. Ishikawa, S. Kimura, M. Yanagisawa, and T. Masaki. 1989. Endothelin activates the dihydropyridine-sensitive, voltage-dependent $\mathrm{Ca}^{2+}$ channel in vascular smooth muscle. Proc. Natl. Acad. Sci. USA. 86:3915-3918.

4. Hirata, Y., H. Yoshimi, S. Takata, T. X. Watanabe, S. Kumagai, K. Nakajima, and S. Sakakibara. 1988. Cellular mechanism of action by a novel vasoconstrictor endothelin in cultured rat vascular smooth muscle cells. Biochem. Biophys. Res. Commun. 154:868-875.

5. Miasiro, N., H. Yamamoto, H. Kanaide, and M. Nakamura. 1988. Does endothelin mobilize calcium from intracellular store sites in rat aortic vascular smooth muscle cells in primary culture? Biochem. Biophys. Res. Commun. 156:312-317.

6. Resink, T. J., T. Scott-Burden, and F. R. Bühler. 1988. Endothelin stimulates phospholipase $C$ in cultured vascular smooth muscle cells. Biochem. Biophys. Res. Commun. 157:1360-1368.

7. Marsden, P. A., N. R. Danthuluri, B. M. Brenner, B. J. Ballermann, and T. A. Brock. 1989. Endothelin action on vascular smooth muscle involves inositol triphosphate and calcium mobilization. Biochem. Biophys. Res. Commun. 158:86-93.

8. Pang, D. C., A. Johns, K. Patterson, L. H. P. Botelho, and G. M. Rubamyi. 1989. Endothelin-1 stimulates phosphatidylinositol hydrolysis and calcium uptake in isolated canine coronary arteries. J. Cardiovasc. Pharmacol. 13(Suppl 5):S75-S79.

9. Kasuya, Y., Y. Takuwa, M. Yanagisawa, S. Kimura, K. Goto, and T. Masaki. 1989. Endothelin-1 induces vasoconstriction through two functionally distinct pathways in porcine coronary artery: contribution of phosphoinositide tumover. Biochem. Biophys. Res. Commun. 161:1049-1055. 
10. Badr, K. F., J. J. Murray, M. D. Breyer, K. Takahashi, T. Inagami, and R. C. Harris. 1989. Mesangial cell, glomerular and renal vascular responses to endothelin in the rat kidney. J. Clin. Invest. 83:336-342.

11. Takuwa, N., Y. Takuwa, M. Yanagisawa, K. Yamashita, and T. Masaki. 1989. A novel vasoactive peptide endothelin stimulates mitogenesis through inositol lipid turnover in Swiss 3T3 fibroblasts. $J$. Biol. Chem. 264:7856-7861.

12. Nishizuka, $Y .1984$. The role of protein kinase $C$ in cell surface signal transmission and tumour promotion. Nature (Lond.). 308:693698.

13. Berridge, M. J., and R. F. Irvine. 1984. Inositol trisphosphate, a novel second messenger in cellular signal transduction. Nature (Lond.). 312:315-321.

14. Martin, T. F. J., S. M. Bajjalieh, D. O. Lucas, and J. A. Kowalchyk. 1986. Thyrotropin-releasing hormone stimulation of polyphosphoinositide hydrolysis in GH3 cell membranes in GTP dependent but insensitive to cholera or pertussis toxin. J. Biol. Chem. 261:1004110049.

15. Smith, C. D., B. C. Lane, I. Kusaka, M. W. Verghese, and R. Snyderman. 1985. Chemoattractant receptor-induced hydrolysis of phosphatidylinositol 4,5-bisphosphate in human polymorphonuclear leukocyte membranes. J. Biol. Chem. 260:5875-5878.

16. Biden, T. J., B. Peter-Piesch, W. Schelegel, and C. B. Wollheim. 1987. $\mathrm{Ca}^{2+}$-mediated generation of inositol 1,4,5-trisphosphate and inositol 1,3,4,5-tetrakisphosphate in pancreatic islets. J. Biol. Chem. 262:3567-3571.

17. Kendall, D. A., and S. R. Nahorski. 1985. Dihydropyridine calcium channel activators and antagonists influence depolarizationevoked inositol phospholipid hydrolysis in brain. Eur. J. Pharmacol. 115:31-36.

18. Wahl, M. I., T. O. Daniel, and G. Carpenter. 1988. Antiphosphotyrosine recovery of phospholipase $\mathrm{C}$ activity after EGF treatment of A-431 cells. Science (Wash. DC). 241:968-970.

19. Grynkiewicz, G. M., M. Poenie, and R. Y. Tsien. 1985. A new generation of $\mathrm{Ca}^{2+}$ indicators with greatly improved fluorescence properties. J. Biol. Chem. 260:3440-3450.

20. Takuwa, Y., N. Takuwa, and H. Rasmussen. 1986. Carbochol induces a rapid and sustained hydrolysis of polyphosphoinositides in bovine tracheal smooth muscle: measurements of the mass of polyphosphoinositides, 1,2-diacylglycerol, and phosphatidic acid. J. Biol. Chem. 261:14670-14675.

21. Preiss, J., C. R. Loomis, W. R. Bishop, R. Stein, J. E. Niedel, and R. M. Bell. 1986. Quantitative measurement of sn-1,2-diacylglycerols present in platelets, hepatocytes, and ras- and sis-transformed normal rat kidney cells. J. Biol. Chem. 261:8597-8600.

22. Waisman, D. M., J. M. Gimble, D. B. P. Goodman, and H. Rasmussen. 1981. Studies of the $\mathrm{Ca}^{2+}$ transport mechanism of human erythrocyte inside-out plasma membrane vasicles. J. Biol. Chem. 256:409-414.

23. Rodbell, M. 1980. The role of hormone receptors and GTP-reg- ulatory proteins in membrane transduction. Nature (Lond.). 284:1722.

24. Goodhardt, M., N. Ferry, P. Geynet, and J. Hanoune. 1982. Hepatic $\alpha_{1}$-adrenergic receptors show agonist-specific regulation by guanine nucleotides. J. Biol. Chem. 257:11577-11583.

25. Okajima, F., T. Katada, and M. Ui. 1985. Coupling of the guanine nucleotide regulatory proteins to chemotactic peptide receptors in neutrophil membranes and its uncoupling by islet-activating protein, pertussis toxin. J. Biol. Chem. 260:6761-6768.

26. Dixon, R. A. F., B. K. Kobilka, D. J. Strader, J. L. Benovic, H. G. Dohlman, T. Frielle, M. A. Bolanowski, C. D. Bennett, E. Rando, R. E. Diehl, et al. 1986. Cloning of the gene and cDNA for mammalian $\beta$-adrenergic receptor and homology with rhodopsin. $\mathrm{Na}$ ture (Lond.). 321:75-79.

27. Kubo, T., K. Fukuda, A. Mikami, A. Maeda, H. Takahashi, M. Mishina, T. Haga, K. Haga, A. Ichiyama, K. Kangawa, M. Kojima, H. Matsuo, T. Horose, and S. Numa. 1986. Cloning, sequencing and expression of complementary DNA encoding the muscarinic acetylcholine receptor. Nature (Lond.). 323:411-416.

28. Fargin, A., J. R. Raymonal, M. J. Lohse, B. K. Kobilka, M. G. Caron, and R. J. Lefkowitz. 1988. The genomic clone G-21 which resembles a $\beta$-adrenergic receptor sequence encodes the $5-\mathrm{HI}_{1 \mathrm{~A}}$ receptor. Nature (Lond.). 335:358-360.

29. Mitsuhashi, T., R. C. Morris, Jr., and H. E. Ives. 1989. Endothelin-induced increases in vascular smooth muscle $\mathrm{Ca}^{2+}$ do not depend on dihydropyridine-sensitive $\mathrm{Ca}^{2+}$ channels. J. Clin. Invest. 84:635-639.

30. Takuwa, Y., Y. Ohue, N. Takuwa, and K. Yamashita. 1989. Endothelin-1 activates phospholipase $\mathrm{C}$ and mobilizes $\mathrm{Ca}^{2+}$ from both extra- and intracellular pools in cultured osteoblastic cells. Am. J. Physiol. In press.

31. Penner, R., G. Matthews, and E. Neher. 1988. Regulation of calcium influx by second messengers in rat mast cells. Nature (Lond.). 334:499-504.

32. Kojima, I., H. Shibata, and E. Ogata. 1986. Pertussis toxin blocks angiotensin II-induced calcium influx but not inositol trisphosphate production in adrenal glomerulosa cells. FEBS (Fed. Eur. Biochem. Soc.) Lett. 204:347-351.

33. Silberberg, S. D., T. C. Poder, and A. E. Lacerda. 1989. Endothelin increases single-channel calcium currents in coronary arterial smooth muscle cells. FEBS (Fed. Eur. Biochem. Soc.) Lett. 247:68-72.

34. Takuwa, Y., and H. Rasmussen. 1987. Measurement of cytoplasmic free $\mathrm{Ca}^{2+}$ concentration in rabbit aorta using the phosphoprotein, aequorin. J. Clin. Invest. 80:248-257.

35. Rasmussen, H., Y. Takuwa, and S. Park. 1987. Protein kinase $\mathrm{C}$ in the regulation of smooth muscle contration. FASEB (Fed. Am. Soc. Exp. Biol.) J. 1:177-185.

36. Takuwa, Y., G. Kelley, N. Takuwa, and H. Rasmussen. 1988. Protein phosphorylation changes in bovine carotid artery smooth muscle during contraction and relaxation. Mol. Cell. Endocrinol. 60:71-86. 